Mihailo Mrdak ${ }^{1 *}$, Časlav Lačnjevac ${ }^{2}$, Marko Rakin $^{3}$, Đorđe Janaćković ${ }^{1}$, Darko Veljić ${ }^{1}$

${ }^{1}$ University of Belgrade, Inovation Center - Faculty of Technology and Metallurgy, Belgrade, Serbia

${ }^{2}$ University of Belgrade, Faculty of Agriculture, Belgrade, Serbi

${ }^{3}$ University of Belgrade, Faculty of Technology and Metallurgy, Belgrade, Serbia
Scientific paper

ISSN 0351-9465, E-ISSN 2466-2585

UDC:621.793.7-034.14:544.344.016.5

https://doi.org/10.5937/zasmat2102106M

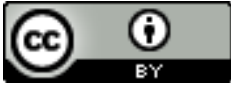

Zastita Materijala 61 (2)

$106-112(2021)$

\title{
Characterization of vacuum plasma spray VPS - W coating deposited on stainless steel substrates
}

\begin{abstract}
In this paper, studied was the melting of $W$ powder particles in plasma, their behavior at oxidation as well as the mechanism of hardening on the surface of the substrate. Tungsten coating layers were deposited with vacuum plasma spray technology (VPS) on the test specimens of steel C.4171 (X15Cr13 EN10027). VPS technology has advantages over the APS technology due to decreased oxidation of melted powder particles, by producing a coating with a controlled proportion of micro pores and greater uniformity of the deposited layers. Evaluation of mechanical characteristics of the layers was done by examining the microhardness using the $\mathrm{HV}_{0.3}$ method and tensile bond strength by tensile testing. The microstructures of the deposited layers were analyzed by means of optical microscopy (OM) and scanning electron microscopy (SEM). The results obtained showed that the tungsten coating consisted of well melted particles that interconnected and were overlapping, which shows a typical lamellar microstructure. Present in the microstructure are micro pores in very small proportion at the inter-lamellar boundaries. Tests have shown that layers of $W$ coating deposited by plasma spray in inert gas shielding at low pressure have good mechanical properties and microstructure, which in the fully enables its use in exploitation.
\end{abstract}

Keywords: tungsten, vacuum plasma spray (VPS), microstructure, interface, microhardness, bond strength.

\section{INTRODUCTION}

Tungsten has a light gray color, good strength and hardness, high density of $19.3 \mathrm{~g} / \mathrm{cm}^{3}$ and the highest melting point of all metals $3422{ }^{\circ} \mathrm{C}$. It has good erosion resistance and is chemically resistant to influence of humidity and air, and is extremely resistant to corrosive acids and bases. Also, tungsten has a very high fire resistance due to which it used for protection from high temperatures. Tungsten is the material for the protective coating in nuclear fusion reactors [1-4]. It is used to make stainless steel, with hard alloys for making wires for lightbulbs and electronic tubes. Tungsten burns easily in the presence of air. Therefore, the W powder is deposited in the protective atmosphere of inert gas or in a vacuum.

\footnotetext{
${ }^{*}$ Corresponding autor: Mihailo Mrdak

e-mail: drmrdakmihailo@gmail.com

Paper received: 14. 12. 2020.

Paper accepted: 17. 01. 2021.

Paper is available on the website:www.idk.org.rs/casopis
}

Vacuum plasma spray (VPS) process compared to the atmospheric plasma spray (APS) process, is conducted in a controlled atmosphere of inert Ar gas at low pressure, which reduces the interaction between the oxidizing surrounding atmosphere with the plasma stream and molten powder particles [5-7]. The VPS technology due to decreased oxidation of the powder produces coatings with a controlled proportion of pores, oxides and with higher uniformity and less contamination [8]. In the vacuum chamber there is always some residual air due to the vacuum level, which could lead to the formation of tungsten $\mathrm{WO}_{3}$ oxide around the surface of the melted or semimelted particles during the deposition process. Therefore, the purity of the Ar is very important since it is used as a shielding atmosphere and an arc gas and the $\mathrm{H}_{2}$ purity, which is used as plasma gas and also a reducing agent. Tungsten oxides mostly occur in the oxidation states: IV $\left(\mathrm{WO}_{2}\right.$, brown), $\mathrm{V}\left(\mathrm{W}_{2} \mathrm{O}_{5}\right.$, blue), and $\mathrm{VI}\left(\mathrm{WO}_{3}\right.$, yellow), but also other types of oxidesappear, such as: $\mathrm{W}_{3} \mathrm{O}$, 
$\mathrm{W}_{4} \mathrm{O}_{3}, \mathrm{WO}, \mathrm{W}_{2} \mathrm{O}_{3}, \mathrm{~W}_{5} \mathrm{O}_{9}, \mathrm{~W}_{4} \mathrm{O}_{8}, \mathrm{~W}_{3} \mathrm{O}_{8}, \mathrm{~W}_{4} \mathrm{O}_{11}$ and $\mathrm{W}_{5} \mathrm{O}_{14}$. The VPS technology has become the most convenient and reliable method for the deposition of $\mathrm{W}$ powder. The reaction of tungsten and oxygen easily occurs at about $400^{\circ} \mathrm{C}$. Yellow $\mathrm{WO}_{3}$ may be formed during the process of plasma spray deposition in the presence of oxygen. Melting and boiling points of $\mathrm{WO}_{3}$ oxide are $1472{ }^{\circ} \mathrm{C}$ and 1837 ${ }^{\circ} \mathrm{C}$ respectively and are much lower than the melting point of tungsten, $3422{ }^{\circ} \mathrm{C}(3695 \mathrm{~K})$, so one part of the formed oxides is reduced prior to the deposition of molten drops on the substrate [9]. In the process of deposition of the powder, it is essential to maintain control of the temperature of the substrate and the deposited layers as in the course of deposition large amounts heat are input, and with the heat high thermal stresses. The large amount of heat causes the formation of residual stress that can cause micro cracks, cracking and flaking of the coating from the surface of the substrate. Therefore, it is very important to control the temperature gradient between the substrate surface and the deposited layers during the process of powder deposition [10]. One of the problems that arise is the mismatch of coefficients of thermal expansion of tungsten coatings and substrate materials, due to which transitional inter layers may develop [11,12]. Another problem that occurs is reduced thermal conductivity of the tungsten plasma spray coating.

The thermal conductivity of the coating is closely related to the production process of the coating and its microstructure [13]. Thermophysical properties of the tungsten coating are key to its use, as a protective coating. Properties of tungsten coatings deposited with plasma spray are associated with the microstructure and oxidation behavior. The microstructure of the coating and oxidation behavior are defined by the spray conditions, such as pressure in the chamber, spray distance and the temperature of the substrate. The values of microhardness and bond strength of the VPS - W coating depends on the $\mathrm{O}_{2}$ content in the coating. With the increase of oxygen content increases the microhardness of the coating, and decreases the value of bond tensile strength [14]. Spray distance has a high influence on the porosity, and hence the wear resistance [15]. For $\mathrm{W}$ powder spraying used is low pressure under a shielded atmosphere of $\operatorname{Ar}$ [16-18]. The stage of melting of powder particles of tungsten at low pressure using the plasma spray process affects their deposition, such as the flattening and stacking on the substrate. To increase the density of the coating, the $\mathrm{W}$ particles should be completely melted, correctly deformed and overlapping with other particles on the substrate. When the tungsten particles are melted at a much higher temperature of $3410^{\circ} \mathrm{C}$ or its melting point, there is ample time for grain growth toward the center of the particle before the particle completely solidifies. As a result, very large grains are formed. Due to the orientation of hardening within the tungsten particle, pores are formed in the center of the tungsten particle. When the melted particle has a temperature close to the melting point of tungsten, during hardening there is no time for grain growth. Consequently, a large number of fine grains form in the tungsten particle. XRD studies have shown that the VPS - W coating consists of cubic tungsten, same as the starting powder [19].

For this paper, the tungsten coating was deposited using vacuum plasma spray technology, for the purpose of obtaining coatings of improved resistance to wards different types of defects such as erosion, high temperature and corrosion. The tungsten coating was deposited on steel substrates. Analyzed were the bond strength between the base material and coating and the microhardness and the microstructure of the coating on optical and scanning electron microscopes (OM, SEM).

For the coating used was tungsten powder with spherical morphology of particles, which were deposited with the F-4 plasma gun onto the test specimens in a vacuum plasma spray chamber of the company Plasma - Technic AG. As the plasma gas used was a mixture of $\mathrm{Ar}$ arc gas of high purity and $\mathrm{H}_{2}$ which acts as a reducing agent during the spraying of melted $W$ drops. In this study, a connection has been established between the vacuum plasma spray parameters and the quality of the obtained coating resistant to various types of damage. Tests have shown that layers of VPS - W coatings had mechanical characteristics and microstructure which fully enable the use of the coating for a wide range of purposes.

\section{EXSPERIMENTAL PART}

\subsection{Materials and experimental details of plasma spray coatings deposition}

For the production of coatings, was used $\mathrm{W}$ powder from Company Inframat ${ }^{\circledR}$ Advanced Materials $^{\mathrm{TM}}{ }^{\mathrm{M}}$, Spherical Tungsten Powder, 99.9\%, label SP7400-1545 with the granulation range from $15 \mu \mathrm{m}$ to $45 \mu \mathrm{m}$. Figure 1 shows the SEM micrograph showing the spherical shape of the $\mathrm{W}$ powder micro particles. 


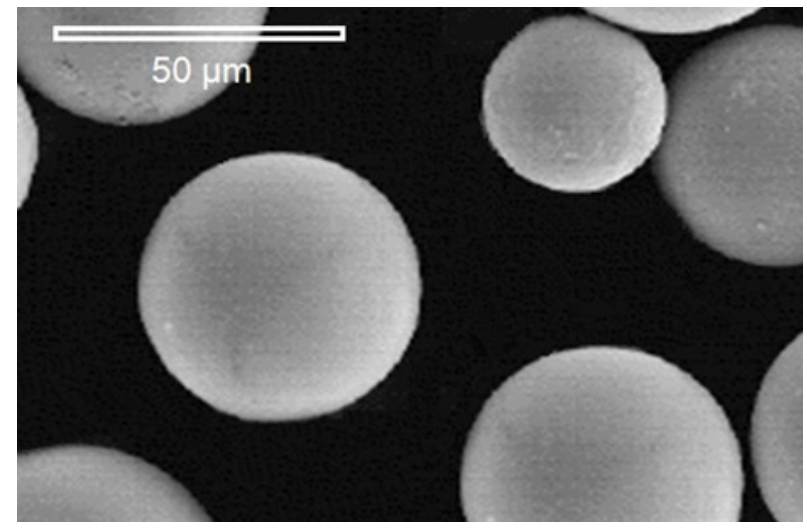

Figure 1. SEM) Scanning electron micrograph of the $W$ powder particles

Slika 1. (SEM) skening elektronska mikrofotografija čestica praha $W$

The substrates onto which the coatings were deposited, for microhardness testing and evaluation of microstructure in the deposited state, were made of Č. 4171 steel (X15Cr13 EN10027) in thermally untreated condition, $70 \times 20 \times 1.5 \mathrm{~mm}$ in size according to the Pratt \& Whitney standard. The bases for testing the bond strength of the coating with the substrate in deposited state were made of Č.4171 (X15Cr13EN10027) steel in thermally untreated condition, $\varnothing 25 \times 50 \mathrm{~mm}$ in size. The coating bond strength is calculated as the maximum load $\left(F_{\max }\right)$ on the sample divided by the area $(A)$ of the fracture of the coating, equation $\sigma=F / A$. The fracture surface area of the samples (A) is calculated from the equation $A=3.14 \times R^{2} / 4$, where $R$ is the measured fracture diameter [20].

Evaluation of the mechanical properties of the layers was done by examining the microhardness using the $\mathrm{HV}_{0.3}$ method and the bond strength by tension testing. Microhardness measuring was carried out in the direction along the lamellae in the middle and at the ends of the samples along the cross-section. Five value readings were made and in this paper will show the average value. The tension method was used for the bond strength evaluation These tests were done at room temperature with tensile speed of $1 \mathrm{~mm} / 60 \mathrm{~min}$. Five samples were examined. Two extreme values were discarded, and the paper shows the average value. The morphology of the $\mathrm{W}$ powder particles and the surface morphology of the deposited layers were analysed by the SEM method. The microstructure of the coating layers in the deposited state was examined by OM and SEM. To see the lamellar structure of the deposited layers, we etched the $\mathrm{W}$ coating, which easily dissolves in the reagent $\mathrm{NaOH}+\mathrm{NaNO}_{3}$. Analysis of the share of micropores in the coating was performed by processing five photos at 200X magnification.
Through tracing paper, the micropores were marked and highlighted and the total area is calculated according to the total micrograph area. This paper shows the average value of the share of pores.

The deposition of the $\mathrm{W}$ powder was performed in an inert $\mathrm{Ar}$ atmosphere at low pressure with a vacuum plasma spray system of the company Plasma - Technik AG. The deposition of the powder was performed by the A-2000 control panel and the F4 plasma gun. The deposition of the powder was done with a mixture of $\mathrm{Ar}-\mathrm{H}_{2}$ plasma.To ensure a high degree of purity, the vacuum chamber was washed with Ar two times before the plasma spray process. High purity Ar 6.0 $(99.9999 \%)$ was then discharged through the anode after the chamber was vacuumed to $10^{-3}$ mbar. High-purity He 6.0 (99.9999\%) and hydrogen (H) $6.0(99.9999 \%)$ were also used. The surfaces of the substrates were roughened with white corundum particles, $0.7-1.5 \mathrm{~mm}$ in size. Prior to the deposition of the powder, the surface of the substrate was cleaned using a transferred arc and the substrate was pre-heated to a temperature of $160{ }^{\circ} \mathrm{C}$. Table 1 shows the VPS parameters of cleaning of the substrate surface and the deposition of the $\mathrm{W}$ powder.

Table 1. The vacuum plasma spray parameters

Tabela 1. Vakuum plazma sprej parametri

\begin{tabular}{|c|c|c|}
\hline \multirow[b]{2}{*}{ Parameters } & \multicolumn{2}{|c|}{ Value } \\
\hline & $\begin{array}{l}\text { Cleaning } \\
\text { Substrate arc }\end{array}$ & Spraying \\
\hline Plasma current, I (A) & 500 & 750 \\
\hline Plasma voltage, U (V) & 65 & 74 \\
\hline $\begin{array}{l}\text { Primarni plazma gas, } \\
\operatorname{Ar}(1 / \mathrm{min} .)\end{array}$ & 50 & 50 \\
\hline $\begin{array}{l}\text { Primary } \mathrm{Ar} \text { plasma gas } \\
\text { flow, } \mathrm{H}_{2}{ }^{1}, \mathrm{He}^{2} \text {, (l/min.) }\end{array}$ & $10^{(1)}$ & $8.5^{(2)}$ \\
\hline $\begin{array}{l}\text { Carrier Ar gas flow, } \\
\operatorname{Ar}(1 / \mathrm{min} .)\end{array}$ & -- & 5 \\
\hline Powder feed rate (g/min) & -- & 18 \\
\hline Substrate distance, $(\mathrm{mm})$ & 270 & 210 \\
\hline $\begin{array}{l}\text { Pressure in chamber, } \\
(\mathrm{kPa})\end{array}$ & 35 & 180 \\
\hline Nozzle anode , (mm) & 8 & 8 \\
\hline $\begin{array}{l}\text { Speed plasma gun, } \\
(\mathrm{mm} / \mathrm{s})\end{array}$ & 250 & 250 \\
\hline
\end{tabular}

The thickness of the coating deposited on the samples for testing the mechanical properties and microstructure was 100-120 $\mu \mathrm{m}$. 


\section{RESULTS AND DISCUSSION}

\subsection{Results of coatings testing}

Within the edge zones of the coating, the average values of microhardness were $329 \mathrm{HV}_{0.3}$ and $327 \mathrm{HV}_{0.3}$. For the middle of the coating the average value of microhardness was $334 \mathrm{HV}_{0.3}$. The microhardness values of the VPS-W coatings along the cross section are uniform, the average value is $330 \mathrm{HV}_{0.3}$, which is slightly lower than that of pure tungsten, the value of which is about 350 $\mathrm{HV}_{0.3}$. The slightly lower value of microhardness is due to the presence of micropores in the deposited layers. The values of the VPS-W coating microhardness indicate that the coating layers show no presence of $\mathrm{WO}_{3}$ oxides - the oxide is yellow and would be seen under a microscope. It is known that $\mathrm{W}$ is unstable in the presence of $\mathrm{O}_{2}$ and that at about $400{ }^{\circ} \mathrm{C}$ it oxidises and forms yellow coloured $\mathrm{WO}_{3}$ oxide in the coatings [9]. Low pressure of inert and high-purity $\mathrm{Ar}$ in a vacuum chamber and the reducing plasma $\mathrm{H}_{2}$ gas prevented the formation of $\mathrm{WO}_{3}$ oxides which increased the microhardness, and this was confirmed by analysing the image with an OM. The VPS-W coating had an average value of tensile bond strength of $40 \mathrm{MPa}$. The mechanism of destruction was the adhesion at the interface between the substrate and the coatings. Cleaning the surface of the substrate using a transferred arc has provided good bonding of the lower layers of the $\mathrm{W}$ coating to the substrate. The measured bond strength values of the VPS-W coatings indicate that, in the layers of the coating, there is a low proportion of micropores and unmolten particles. The values of microhardness and tensile bond strength of the $\mathrm{W}$ coating were directly related to their microstructures, as confirmed by the coating microstructure analysis.

Figure 2 shows the microstructure of the VPS$W$ coating layers in the deposited state. The image represents the typical microstructure of the plasma sprayed coating, which is made of molten tungsten particles. The cross section of the spread $W$ particles exhibits a lamellar structure. Lamella structure consists of $\mathrm{W}$ with a body-centered cubic structure (bcc) [19]. Within the microstructure of the coating, in Figure3, can see micropores of irregular shape, which are directly related to the improper packing of semi-molten particles and precipitates. Formation of the first layer of deposited W lamellae on the surface of the substrate is essential to the bond strength between the coating and the substrate. One of the important factors for good bonding of the deposited lamellae with the substrate is the pre-heating temperature of the substrate.

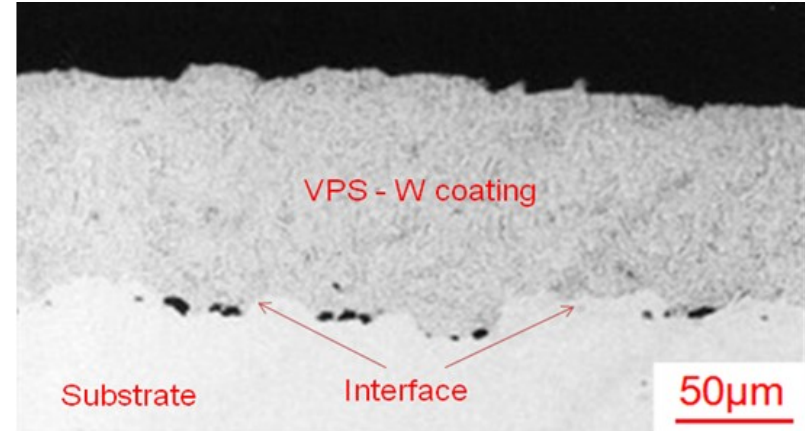

\section{Figure 2. (OM) Microstructure of $W$ coatings in deposited state}

Slika 2. (OM) mikrostruktura $W$ prevlake $u$ deponovanom stanju

Preheating of the substrate favourably influenced the spread and proper formation of the deposited particles. Contact between the lamellae and the substrate is improved with the pre-heating of the substrate [21]. The correct shape of the deposited particles in the form of a disc increases the adhesion of the coating to the substrate and the lamellar cohesive strength. Between the layers of the coating there were no inter-lamellar boundaries due to good cohesive connections of the lamellae and a small amount of micropores. The amount of micropores in the layers of the deposited coating was $1 \%$.

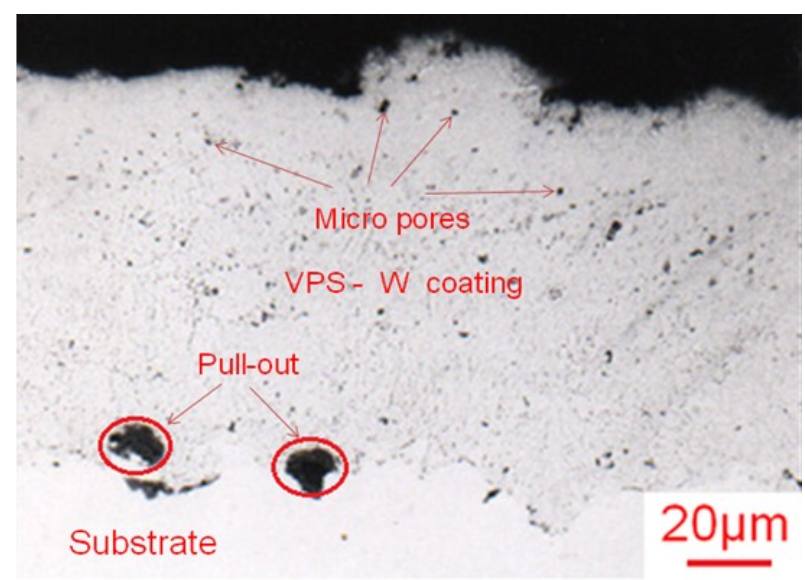

Figure 3. (OM) Microstructure of $W$ coatings in deposited state

\section{Slika 3. (OM) mikrostruktura W prevlake $u$ deponovanom stanju}

The deposits made of semi-molten and irregularly deformed particles have poor adhesion, cohesion, and high porosity. A large number of splattered liquid drops on the substrate has a detrimental effect and causes the formation of rough irregularly-shaped voids which are difficult to fill with subsequent droplets that emerge in the deposition process up to the formation of the final thickness of the coating [22]. A qualitative analysis 
showed that the interface between the substrate and the deposited coatings did not show defects such as discontinuity of the deposited layers, cracks and separation of the coating from the base. In some places, at the substrate/coating interface, there are dark areas formed by $\mathrm{Al}_{2} \mathrm{O}_{3}$ oxide particle during the roughing of the substrates. It is clearly visible that these dark areas retain the morphology of an original $\mathrm{Al}_{2} \mathrm{O}_{3}$ oxide particle with its angular and sharp edges (Fig.2). Within the vicinity of the interface with the substrate, along the coating, in one place is observed approximately spherical black observed spherical and black pull-outs (Fig.2). The interface boundaries between the substrate and coating layers were cleaned well with a transferred arc.

Figure 4 shows the SEM micrograph of the cross-section of the tungsten coating etched with reagent $\mathrm{NaOH}+\mathrm{NaNO}_{3}$ by reaction $2 \mathrm{~W}+2 \mathrm{NaOH}$ $+7 \mathrm{NaNO}_{3}=2 \mathrm{NaWO}_{4}+7 \mathrm{NaNO}_{2}+\mathrm{H}_{2} \mathrm{O}$. During the reaction, an inorganic sodium tungsten compound was formed - a white solid substance $\mathrm{NaWO}_{4}$, sodium nitrate $\mathrm{NaNO}_{3}$ and water $\mathrm{H}_{2} \mathrm{O}$. We can clearly see the lamellar microstructure of the $\mathrm{W}$ coating thermal spray. Within the coating, we observed different types of micropores which were black and of irregular and nearly spherical shape. The coating showed no inter-lamellar linear pores along the coating, which are always parallel to the substrate. The connections between the lamellae and the lamellar layers are not clear, which indicates that, in the process of deposition, oxidation of the powder and separation of the oxide lamellae along the boundaries of the $\mathrm{W}$ lamellae did not occur [18]. The microstructure of the coating showed that the phenomenon of oxidation during the vacuum plasma spray process was suppressed [23].

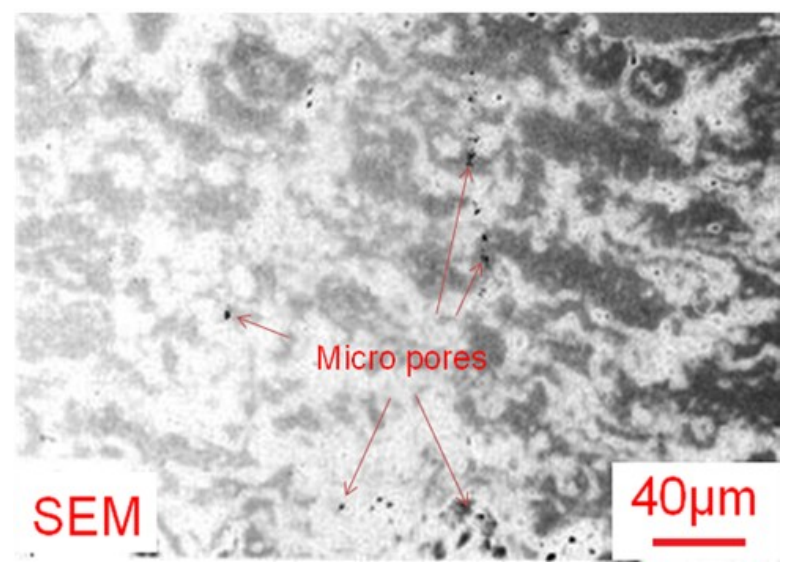

Figure 4. (SEM) microstructure of $W$ coatingsin in etched conditions

Slika 4. (SEM) mikrostruktura $W$ prevlake $u$ nagrizenom stanju
SEM analysis of the surface morphology of the $W$ coating showed complete melting and spreading of melted $\mathrm{W}$ particles on the previously deposited layer, as can be seen in Figure 5.

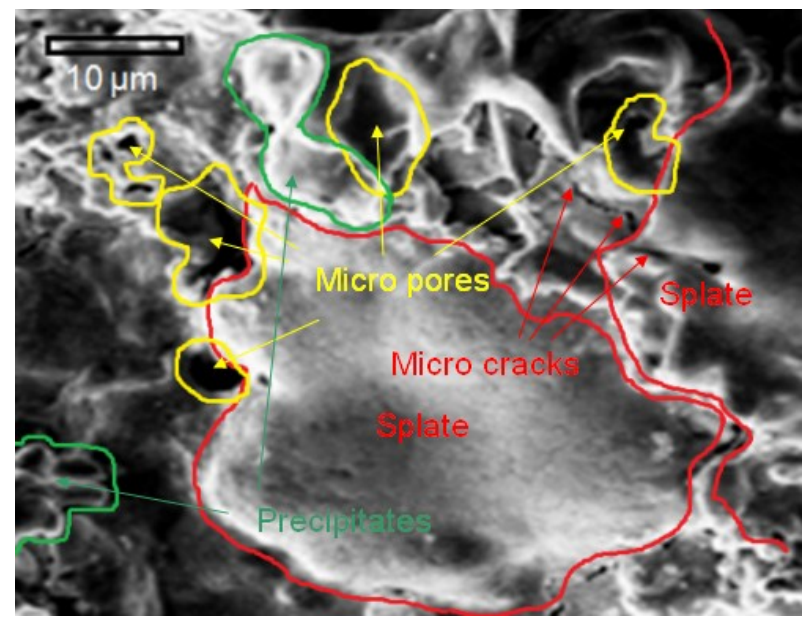

Figure 5. (SEM) micrograph of $W$ coatings surface

Slika 5. (SEM) mikrografija površine W prevlake

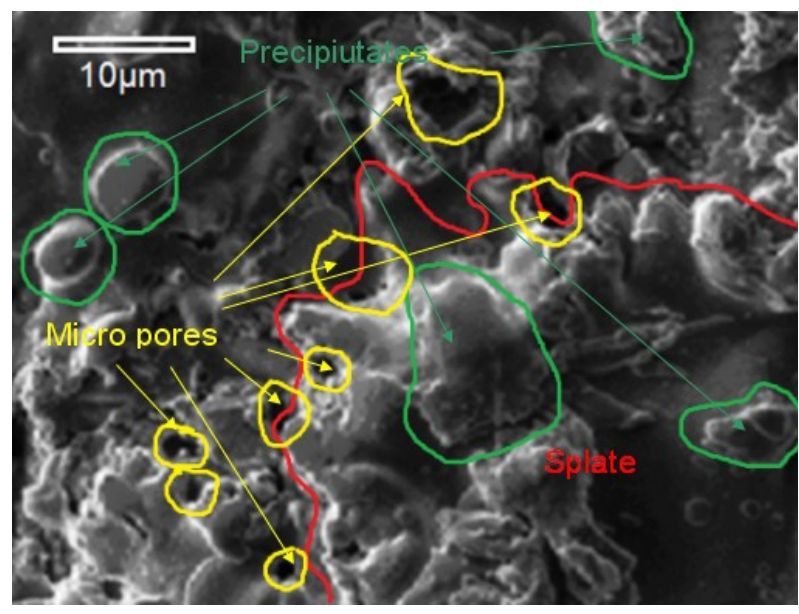

Figure 6. (SEM) (SEM) micrograph of $W$ coatings surface

\section{Slika 6. (SEM) mikrografija površine $W$ prevlake}

In the SEM micrograph marked with a red line are two completely melted and properly flattened $\mathrm{W}$ powder particles. The completely melted powder particles formed thin discs - splats in collision with the surface of the previously deposited layers. The morphology of the deposited particles confirmed that the molten particles in collision with the substrate formed the regular form and as such achieved a good connection with the previously deposited particles. On the surface of the coating in one spot evident is a fine micro-crack, which indicates that on the surface of the coating there is stress concentration present which could affect the formation of cracks in the coating. However, the 
cross-sectional SEM examination of the $\mathrm{W}$ coating (Fig.4) showed that in the coating are no present micro and macro cracks.

In the microstructure present are precipitates roughly of spherical shapewhich are circledin green. The precipitates resulted from the breaking away of parts of the melted droplets in collision with a previously deposited layer. The broken pieces after hardening remained in the coating as residue. In the microstructure at the boundaries ofthe deformed particles observed were micro pores irregularly shaped circled in yellow. The SEM micrograph (Fig.6) shows the typical point where the rough surface the $W$ coating can be seen composed of a melted powder particle circled in red, and precipitates and fine micro pores circled in yellow. In this part of the coating surface there are no micro cracks present.

\section{CONCLUSIONS}

In this paper, using the VPS - vacuum plasma spray process, $W$ coatings were deposited on steel substrates. The microstructure and mechanical properties of the coating layers and the coating surfaces were analayzed, based on which the following conclusions were made.

The VPS-W coating had a mean microhardness value of $330 \mathrm{HV}_{0.3}$ and bond tensile strength of $40 \mathrm{MPa}$. The microhardness and bond tensile strength values suggest that the coating layers contain no $\mathrm{W}$ oxides, which increases the microhardness and reduces the adhesion of the coating. This has been confirmed by a metallographic examination of the coating. The mechanism of destruction was the adhesion at the interface between the substrate and the coatings.

The $\mathrm{W}$ coating microstructure is lamellar. The basis of the lamellae consists of $W$ with a bodycentred cubic lattice. There are no inter-lamellar oxides present in the coating layers. Due to good cohesive connections of lamellae, there are no inter-lamellar boundaries through the coating layers. The coating contains a small proportion of micropores in the amount of $1 \%$. The SEM analysis of the surface morphology of the $\mathrm{W}$ coating showed that $\mathrm{W}$ particles, on the previously deposited layer, completely melted and spread. The morphology of the deposited particles showed that the molten $\mathrm{W}$ droplets in collision with the substrate formed a correct shape and as such achieved a good connection with the previously deposited particles. At one point, on the surface of the coating, we observed a micro crack which did not extend through the cross-section of the coating. This was confirmed by the SEM examination of the W coating cross-section.
Tests have shown that layers of the VPS-W coating have mechanical properties and microstructure which completely allow the use of the coating as a protection against erosion, corrosion and high temperatures.

\section{Acknowledgement}

"This work was supported by the ministry of education, science and technological development of the republic of serbia (contract no. 451-0368/2021-14/ 200287)".

\section{REFERENCES}

[1] S.Boire-Lavigne, C.Moreau, R.G.Saint-Jacques (1993) Taguchi analysis of the influence of plasma spray parameters on the microstructure of tungsten coatings $[A]$. International Symposium on Developments and Applications of Ceramics and New Metal Alloys [C]. Quebec City, p.473-485.

[2] A.Cavasin, T.Brzezinski, S.Grenier, et al. (1998) W and $\mathrm{B}_{4} \mathrm{C}$ coatings for nuclear fusion reactors $[\mathrm{A}]$. International Thermal Spray Conference [C]. France: Nice, p.957-962.

[3] W.Mallener, W.Hohenauser, D.Stoever (1996) Tungsten coatings for nuclear fusion devices [A]. Proceedings of the 9th National Thermal Spray Conference [C]. Cincinnatti, p.1-6.

[4] R.Raman, J.C.Thomas, D.Q,Hwang, et al. (1993) Design of the compact toroid fueler for center fuelling tokamak de varennes [J]. Fusion Technology, 24, 239-250.

[5] M.Mrdak, Č.Lačnjevac, M.Rakin (2018) Mechanical and structural features of $\mathrm{Nb}$ coating layers deposited on steel substrates in a vacuum chamber, Zastita materijala, 59 (2), 167-172.

[6] M.Mrdak, Č.Lačnjevac, M.Rakin, N.Bajić (2018) Characterization of tantalum coatings deposited using vacuum plasma spray process, Zastita materijala, 59 (4), 489-494.

[7] M.Mrdak, Č.Lačnjevac, M.Rakin, N.Bajić, D.Veljić (2019) Karakterizacija plazma sprej bioinertne prevlake $\mathrm{Al}_{2} \mathrm{O}_{3} 28$ tež. $\% \mathrm{MgO}$, Zastita materijala, 60 (1), 44-50.

[8] Z.Salhi, D.Klein, P.Gougeon, C.Coddet (2005) Development of coating by thermal plasma spraying under very low-pressure condition $<1$ mbar, Vacuum, 77, 145-150.

[9] A.Warren, A.Nylund, I.Olefjord (1996) Oxidation of tungsten and tungsten carbide in dry andhumidatmospheres, International Journal of Refractory Metals and Hard Materials, 14, 345-353.

[10] E.Fortuna, M.J.Rubel, M.Psoda, M.Andrzejczuk, K.J.Kurzydlowski, M.Miskiewicz, V.Philipps, A. Pospieszczyk, G.Sergienko, M.Spychalski, W.Zielinski (2007) Plasma-induced damage of tungsten coatings on graphite limiters, Physica Scripta, T128,162-165.

[11] G.Pintsuk, S.E.Brunings, J.E.Doring, J.Linke, I.Smid, L.Xue (2003) Development of W/Cufunctionally graded materials, Fusion Engineering and Design, 66-68, 237-240. 
[12] K.Tokunaga, N.Yoshida, N.Noda, Y.Kubota, S.Inagaki, R.Sakamoto, T.Sogabe, L.Plochl (1999) Behavior of plasma-sprayed tungsten coatings on CFC and graphite under high heat load, Journal of Nuclear Materials, 266-269, 1224-1229.

[13] H.Bolt, V.Barabash, W.Krauss, J.Linke, R.Neu, S.Suzuki, N.Yoshida (2004) ASDEX Upgrade Team, Materials for the plasma-facing components of fusion reactors, Journal of Nuclear Materials, 329-333, 66-73.

[14] F.L.Chong, J.L.Chen, J.G.Li, D.Y.Hu, X.B.Zheng (2008) Heat load behaviors of plasma sprayed tungsten coatings on copper alloys with different compliant layers, Journal of Nuclear Materials, 375, 213-217.

[15] T.A.Stolarski, S.Tobe (2001) The effect of spray distance on wear resistance of Mo coatings [J]. Wear, 249, 1096-1102.

[16] W.Cai, H.Liu, A.Sickinger, et al. (1994) Lowpressure plasma deposition of tungsten [J]. Journal of Thermal Spray Technology, A3(2), 135-141.

[17] X.L.Jiang, M.I.Boulos (2001) Particle melting, flattening, and stacking behaviors in the induction plasma deposition of tungsten [J]. Transactions of Nonferrous Metals Society of Chinam, 11(5), 811816.
[18] H.K.Kang (2004) Thermal properties of plasmasprayed tungsten deposits, Journal of Nuclear Materials, 335, 1-4.

[19] Y.Niu, X.Zheng, H.Ji, L.Qi, C.Ding, J.Chen, G.Luo, (2010) Microstructure and thermal property of tungsten coatings prepared by vacuum plasma spraying technology, Fusion Engineering and Design, 85, 1521-1526.

[20] Turbojet Engine - Standard Practices Manual PN 582005 (2002) Pratt \& Whitney, East Hartford, USA.

[21] M.Mrdak, A.Vencl, B.Nedeljkovic, M.Stanković (2013) Influence of plasma spraying parameters on properties of the thermal barrier coatings, Materials Science and Technology, 29(5), 559-567.

[22] A.T.T.Tran, M.M.Hyland, K.Shinoda,, S.Sampath (2011) Influence of Substrate Surface Conditions on the Deposition and Spreading of Molten Droplets, Thin Solid Films, 519, 2445-2456

[23] D.Hu, X.Zheng, Y.Niu, H.Ji, F.Chong, J.Chen (2008) Effect of oxidation behavior on the mechanical and thermal properties of plasma sprayed tungsten coatings, Journal of Thermal Spray Technology, 17, 377-384.

\section{IZVOD}

\section{KARAKTERIZACIJA VAKUUM PLAZMA SPREJ VPS - W PREVLAKE DEPONOVANE NA ČELIČNIM PODLOGA}

U ovom radu proučavano je topljenje čestica praha W u plazmi, njihovo ponašanje na oksidaciju
kao i mehanizam očvršćavanja na površini substrata. Slojevi volfram prevlake su deponovani sa
vakuum plazma sprej tehnologijom (VPS) na ispitnim uzorcima od čelika Č.4171 (X15Cr13
EN10027). VPS tehnologija ima prednosti u odnosu na APS tehnologiju zbog smanjene oksidacije
istopljenih čestica praha, proizvodeći prevlaku sa kontrolisanim udelom mikro pora i većom
uniformnosti deponovanih slojeva. Procena mehaničkih karakteristika slojeva je urađena
ispitivanjem mikrotvrdoće metodom HV H. $_{\text {o. }}$ i zatezne čvrstoće spoja ispitivanjem na zatezanje.
Analizirane su mikrostrukture deponovanih slojeva pomoću optičke mikroskopije (OM) i skening
elektronske mikroskopije (SEM). Dobijeni rezultati su pokazali da se volfram prevlaka sastojala od
dobro istopljenih čestica međusobno povezanih i preklopljenih, koja pokazuje tipičnu lamelarnu
mikrostrukturu. U mikrostrukturi su prisutne mikro pore u veoma malom udelu koje se nalaze na
među-lamelarnim granicama. Ispitivanja su pokazala da slojevi $W$ prevlake deponovani plazma
sprejom u zaštritnoj atmosferi inertnog gasa na niskom pritisku imaju dobre mehaničke osobine i
mikrostrukturu, koje u potpunosti omogućavaju njenu primenu u eksploataciji.

Ključne reči: volfram, vakuum plazma sprej (VPS), mikrostruktura, interfejs, mikrotvrdoća, čvrstoća spoja

Naučni rad

Rad primljen: 14. 12. 2020.

Rad prihvaćen: 17. 01. 2021.

Rad je dostupan na sajtu: www.idk.org.rs/journal

(C) 2021 Authors. Published by Engineering Society for Corrosion. This article is an open access article distributed under the terms and conditions of the Creative Commons Attribution 4.0 International license (https://creativecommons.org/licenses/by/4.0/) 